\title{
ANALISIS JARINGAN KOMUNIKASI MASYARAKAT DALAM KESIAPAN MENGHADAPI BENCANA LONGSOR DI KAKI GUNUNG BURANGRANG KABUPATEN BANDUNG BARAT
}

\author{
Ditha Prasanti dan Ikhsan Fuady \\ Fakultas Ilmu Komunikasi Universitas Padjadjaran \\ Email: ditha.prasanti@unpad.ac.id
}

\begin{abstract}
West Bandung Regency is an area that has hilly topography and mountains. It causes the area of West Bandung to be prone to landslides. One way that can be done to reduce the risk of landslide disaster is to improve the effective communication network. This study aims to describe and analyze the community communication network In Landslide Preparedness Facing Landslide at Burangrang Mountain Foot Kabupaten West Bandung. This research method use approach of communication network analysis using Ucinet 6.0. The results showed that the structure of risk communication network network is personalized interlocking (interlocking personal network). The average value of local centrality on this network is 4.113 . Based on the results of the analysis that has been done, there are several clicks in the communication network; some actors who act as star in the network; some isolate individuals who do not get or relate to other parties to obtain information related to landslide disaster.
\end{abstract}

Keywords: Communication Network; Disaster; Landslide; West Bandung.

\begin{abstract}
ABSTRAK
Kabupaten Bandung Barat merupakan kawasan yang memiliki topografi perbukitan dan pegunungan. Hal tersebut menyebabkan kawasan Bandung Barat menjadi daerah rawan longsor. Salah satu cara yang dapat dilakukan untuk menurunkan risiko bencana longsor adalah meningkatkan jaringan komunikasi yang efektif. Penelitian ini bertujuan untuk mendeskripsikan dan menganalisis jaringan komunikasi Masyarakat Dalam Kesiapan Menghadapi Bencana Longsor di Kaki Gunung Burangrang Kabupaten Bandung Barat. Metode penelitian ini menggunakan pendekatan analisis jaringan komunikasi dengan menggunakan Ucinet 6.0. Hasil penelitian menunjukkan bahwa bentuk struktur jaringan komunikasi risiko bersifat personal memusat (interlocking personal network). Nilai rata-rata sentralitas lokal pada jaringan ini adalah 4,113. Berdasarkan hasil analisis yang telah dilakukan, terdapat beberapa klik dalam jaringan komunikasi; beberapa aktor yang berperan sebagai star dalam jaringan; beberapa individu isolate yang tidak mendapatkan atau berhubungan dengan pihak lain untuk mendapatkan informasi terkait bencana longsor.
\end{abstract}

Kata Kunci: Bandung Barat; Bencana; Jaringan Komunikasi; Longsor. 


\section{PENGANTAR}

Kabupaten Bandung Barat merupakan wilayah pemekaran dari kabupaten Bandung yang penduduknya sebagian besar bermata pencaharian sebagai petani. Sebagian besar topografi Bandung Barat didominasi oleh perbukitan dan gunung yang menyebabkan sering terjadinya peristiwa tanah longsor pada lereng potongan di atas badan jalan, terutama pada musim hujan. Banyaknya frekuensi bencana longsor di atas badan jalan telah menimbulkan munculnya kerugian fisik yaitu kerusakan jalan dan kerugian ekonomis seperti terputusnya jalur transportasi.

Eksplorasi lahan pertanian di Bandung Barat yang berlebihan daya dukung lingkungan berdampak pada kerusakan lingkungan dan bencana alam secara masif. Rendahnya pemahaman masyarakat tentang pengelolaan lahan pertanian yang berkelanjutan mempercepat kerusakan ekosistem dan menyebabkan kerentanan bencana longsor. Aktivitas pertanian yang dilakukan sepanjang tahun dengan budidaya tanaman semusim menyebabkan degradasi lahan pertanian dan lahan semakin rawan bencana longsor.

Berdasarkan data dari Badan Nasional Penanggulangan Bencana (BNPB), kejadian bencana longsor di Bandung Barat senantiasa mengalami peningkatan yang cukup signifikan. Sejak tahun 2008 hingga tahun 2016, bencana longsor di Bandung Barat mencapai 55 kali bencana yang mengakibatkan kerugian cukup besar, sebanyak 35 korban meninggal, 5 orang hilang, orang terluka, dan 1.040 orang mengungsi akibat bencana longsor (BNPB, 2017).

Badan Nasional Penanggulangan Bencana menyebutkan bahwa paling tidak ada empat faktor dominan yang menjadi penyebab masih tingginya angka korban dan kerugian akibat bencana, yaitu (a) kognisi tentang ciri atau tanda tanda bahaya; (b) afeksi dan konasi perilaku yang mengakibatkan degradasi kualitas sumber daya alam; (c) minimnya pemberitahuan ataupun informasi dini yang mengakibatkan ketidaksiapsiagaan warga; dan (d) ketidakberdayaan atau ketidakmampuan dalam menghadapi ancaman bahaya. Walau- pun berbagai upaya telah dilakukan oleh berbagai pihak dalam upaya untuk penurunan kerugian atau risiko bencana, telah dilakukan usaha usaha dari berbagai pihak baik oleh pemerintah pusat maupun daerah ataupun non pemerintah maupun masyarakat, tetapi kejadian bencana dari waktu ke waktu tetap menunjukkan terjadinya peningkatan baik frekuensinya maupun dampak kerugiannya (BNPB, 2017).

Tingginya kerugian akibat bencana longsor disebabkan oleh rendahnya komunikasi dan koordinasi yang efektif antar masyarakat, sehingga hal ini berimplikasi pada rendahnya usaha pencegahan terjadinya bencana longsor. Usaha penanggulangan risiko bencana akibat kerusakan lingkungan dan menjaga kelestarian lingkungan merupakan salah satu tujuan yang sangat penting dilakukan dan tertuang dalam tujuan dalam butir tujuan Pembangunan Berkelanjutan (Sustainable Development Goals/ SDGs) yaitu melindungi, memulihkan dan memajukan penggunaan ekosistem bumi, melakukan pengelolaan alam dan hutan secara sustainable, memerangi desertifikasi dan menghentikan kepunahan keanekaragaman hayati, mempunyai 12 target yang harus dicapai, dan juga common goals Jawa Barat nomor enam, yaitu meningkatkan Pengelolaan lingkungan hidup dan kebencanaan (sub tujuan, Penanganan bencana longsor, dan banjir).

Dalam rangka mengurangi risiko kerugian yang besar akibat bencana longsor, diperlukan suatu strategi komprehensif dan koordinatif lintas sektoral. Paradigma sistem penanggulangan bencana saat ini menuntut masyarakat lebih berperan aktif dalam penurunan risiko bencana. Tanggung jawab penurunan risiko bencana tentu tidak hanya berada sepenuhnya pada pemerintah pusat, tetapi juga menjadi tanggung jawab pemerintah daerah.

Dalam penurunan risiko bencana, partisipan yang terhubung dalam jaringan komunikasi antara lain pemerintah, LSM, relawan, masyarakat di wilayah rawan bencana, para donatur, perusahaan media massa, dan lembaga asing (Puspito, 2014). Untuk 
menurunkan risiko bencana, tentu memerlukan suatu analisis jaringan komunikasi yang efektif agar kegiatan penurunan risiko bencana dapat berjalan secara optimal.

Berdasarkan uraian latar belakang di atas, peneliti tertarik untuk mengangkat penelitian ini yang bertujuan untuk mendeskripsikan dan menganalisis jaringan komunikasi masyarakat dalam kesiapan menghadapi bencana longsor di kaki gunung Burangrang, Kabupaten Bandung Barat, yang akan membangun suatu jaringan komunikasi risiko yang terjadi di masyarakat, serta mengidentifikasi efektivitas komunikasi risiko dalam kesiapan menghadapi bencana tanah longsor di kawasan kaki tersebut.

Rudianto (2015) menjelaskan bahwa terminologi komunikasi bencana saat ini belum menjadi konsep populer dalam bidang komunikasi maupun bidang kebencanaan. Walaupun sudah banyak penelitian komunikasi bencana yang telah dilakukan, baik dalam negeri atau di luar negeri, tetapi kajian komunikasi bencana di Indonesia masih sangat terbatas. Para peneliti mulai tertarik untuk melakukan kajian komunikasi bencana pasca-bencana tsunami Aceh pada tahun 2004. Akan tetapi, kesadaran akan pentingnya komunikasi dalam usaha mitigasi bencana semakin tinggi satu dekade terakhir. Salah satu titik penting yang menjadi perhatian terkait komunikasi dalam bencana adalah masalah ketidakpastian.

Prasanti dan Fuady (2017) mengemukakan bahwa upaya yang harus dilakukan dalam mengatasi hambatan komunikasi yang terjadi guna penanggulangan bencana, diperlukan suatu strategi komunikasi yang interaktif antarmasyarakat dengan mempertimbangkan ketepatan sumber, pemilihan media, dan karakteristik komunikan. Untuk mengidentifikasi elemen tersebut, Zulkarnain (2015) menambahkan bahwa untuk meningkatkan efektivitas jaringan komunikasi diperlukan identifikasi aktor aktor kunci yang berperan sebagai star, cosmopolite, dan gate keeper dalam jaringan komunikasi tersebut.

Dalam mitigasi sebelum dan pascabencana, informasi yang tepat, cepat, dan akurat sangat dibutuhkan oleh masyarakat maupun lembaga swasta baik masyarakat yang rawan terkena bencana maupun stakeholder lainnya. Komunikasi dalam mitigasi bencana tidak hanya dibutuhkan dalam kondisi darurat bencana, tetapi juga penting pada prabencana dan pascabencana. Oleh karena itu, peneliti juga dapat mengatakan bahwa komunikasi merupakan salah satu cara yang efektif untuk kesuksesan mitigasi bencana, persiapan, respon, dan pemulihan situasi pada saat bencana.

Kemampuan untuk mengkomunikasikan pesan-pesan tentang bencana kepada publik, pemerintah, media dan pemuka pendapat dapat mengurangi risiko, menyelamatkan kehidupan, dan dampak dari bencana (Haddow dan Haddow, 2008: 2). Susanto (dalam Budi dkk, 2011: 17) menjelaskan bahwa untuk mengintegrasikan karakter masyarakat kawasan rawan bencana dengan regulasi pemerintah dalam penanganan bencana, dapat tercapai dengan baik jika kedua belah pihak mampu menciptakan komunikasi kohesif yang menghasilkan pemahaman bersama. Akan tetapi, persoalannya dalam kondisi darurat bencana, membuka sinyal komunikasi untuk menangani korban dengan cepat tidak mudah untuk dilaksanakan.

Penelitian ini dilaksanakan di Desa Cimanggu Kecamatan Ngamprah Kabupaten Bandung Barat. Data artikel ini dilakukan pada Bulan Juli 2017. Populasi penelitian terdiri dari kepala keluarga di Desa Desa Cimanggu Kecamatan Ngamprah Kabupaten Bandung Barat. Upaya yang dilakukan dalam membantu menemukan realitas sosial untuk memetakan (mapping) jaringan komunikasi antarmasyarakat yang rawan terdampak bencana longsor, responden diambil dengan teknik sampling menggunakan intact system (Rogers dan Kincaid, 1981), dengan intact system, semua individu yang menjadi kepala keluarga di Desa Cimanggu yang rawan terdampak bencana longsor adalah satu sistem sosial. Responden yang dijadikan unit contoh adalah kepala keluarga. Pemilihan metode analisis jaringan komunikasi ini karena teknik analisis ini dapat mendeskripsikan jaringan komunikasi dengan sosiogram dan bertitik tolak dari analisis konvergensi yang berpijak 
pada teori cybernetic, yaitu teori yang melihat tingkah laku manusia dari sudut pandang sistem sosial (Rogers dan Kincaid, 1981). Teori ini memiliki asumsi bahwa perilaku individu akan sangat ditentukan oleh hubungan atau relasi sosialnya daripada karakteristik individu itu sendiri. Analisis jaringan ini menggunakan aplikasi Ucinet 6.0 for windows.

Adapun teknik pengumpulan data yang dilakukan pada penelitian ini yaitu melalui kuesioner, observasi, dan dokumentasi. Penelitian ini didesain sebagai penelitian kuantitatif. Untuk menjawab tujuan penelitian ini, maka analisis data yang digunakan adalah dengan analisis kuantitatif. Untuk mengetahui bentuk atau pola komunikasi risiko pada masyarakat, sentralitas global, sentralitas lokal, betweeness, serta kohesivitas jaringan komunikasi risiko, analisis ini akan menggunakan program Ucinet 9.0.

Lokasi penelitian ini adalah desa Cimanggu, kaki gunung Burangrang yang berada di Kabupaten Bandung Barat dengan mempertimbangkan kriteria seringnya terjadi bencana longsor di desa tersebut. Alasan pemilihan lokasi penelitian adalah berdasarkan pada hasil survei tentang bencana longsor terbanyak di kaki gunung Burangrang Kabupaten Bandung Barat.

\section{PEMBAHASAN}

Masyarakat di desa Cimanggu, Kecamatan Ngamprah merupakan masyarakat yang sebagian tinggal di kawasan perbukitan dan rawan bencana longsor. Untuk menurunkan risiko bencana, tentu memerlukan suatu strategi komunikasi yang efektif agar kegiatan penurunan risiko bencana dapat berjalan secara optimal. Untuk mengurangi risiko bencana longsor, masyarakat harus terhubung dalam sebuah jaringan komunikasi pihak terkait seperti pemerintah, LSM, relawan, masyarakat di wilayah rawan bencana, para donasi, perusahaan media masa, dan lembaga asing (Puspito, 2014).

Dalam rangka mencariupaya pengurangan reisiko bencana longsor, peneliti melakukan pemetaan terhadap pola komunikasi masyarakat di beberapa dusun di Desa Cimanggu kecamatan Ngamprak Bandung Barat. Desa Cimanggu ini merupakan desa yang terletak di lereng gunung Burangrang. Penelitian ini melakukan penggalian data di enam dusun, yaitu dusun Pangkalan, dusun Gandasuli, dusun Cimanggu, dusun Cikawao, dusun Cibaligo, dan dusun Epen.

Selain itu, peneliti pun mengidentifikasi aktor-aktor dalam jaringan komunikasi ini. Oleh karena itu, peneliti melakukan spesifikasi analisis jaringan komunikasi pada masyarakat desa Cimanggu yang sangat rawan terdampak bencana longsor, yaitu dusun Epen.

Masyarakat yang berada di desa Cimanggu tersebut membentuk jaringan komunikasi sebagai upaya dalam memenuhi kebutuhan informasi dalam rangka mitigasi bahaya risiko dari bencana longsor, baik di wilayah pemukiman maupun lahan pertanian, guna mengurangi risiko. Jaringan komunikasi yang terbentuk dari interaksi antara masyarakat merupakan bentuk interaksi antar masyarakat yang menunjukkan perilaku komunikasi mereka dalam memberi, menerima, dan menyebarluaskan sebuah informasi. Analisis terhadap jaringan komunikasi menghasilkan sosiogram yang menggambarkan struktur komunikasi yang terjalin di antara masyarakat. Dalam rangka memetakan perilaku komunikasi risiko pada masyarakat yang tinggal dikawasan rawan longsor ini, peneliti melakukan identifikasi (a) struktur jaringan komunikasi; (b) sentralitas lokal; (c) betweenness; dan (d) identifikasi aktor.

\section{Analisis Struktur Jaringan Komunikasi}

Struktur jaringan komunikasi mengenai penyebaran informasi tentang adanya risiko bencana longsor di antara masyarakat terbentuk karena interaksi antar masyarakat dengan individu dalam dan luar desa. Jumlah aktor (node) yang terlibat dalam jaringan komunikasi mengenai Informasi risiko bencana longsor di Desa Cimanggu pada penelitian ini adalah 71 aktor yang terdiri dari 34 aktor merupakan warga kampung Epen yang rawan terkena bencana longsor, serta 36 aktor (Node) di luar kampung Epen yang terdiri dari warga 
dusun Cimanggu, Cikawawo, Pasir Jeunjing, Gandasuli, Pangkalan, dan aparat desa Cimanggu. Sosiogram jaringan komunikasi bencana longsor di desa Cimanggu dapat dilihat pada Gambar 1.

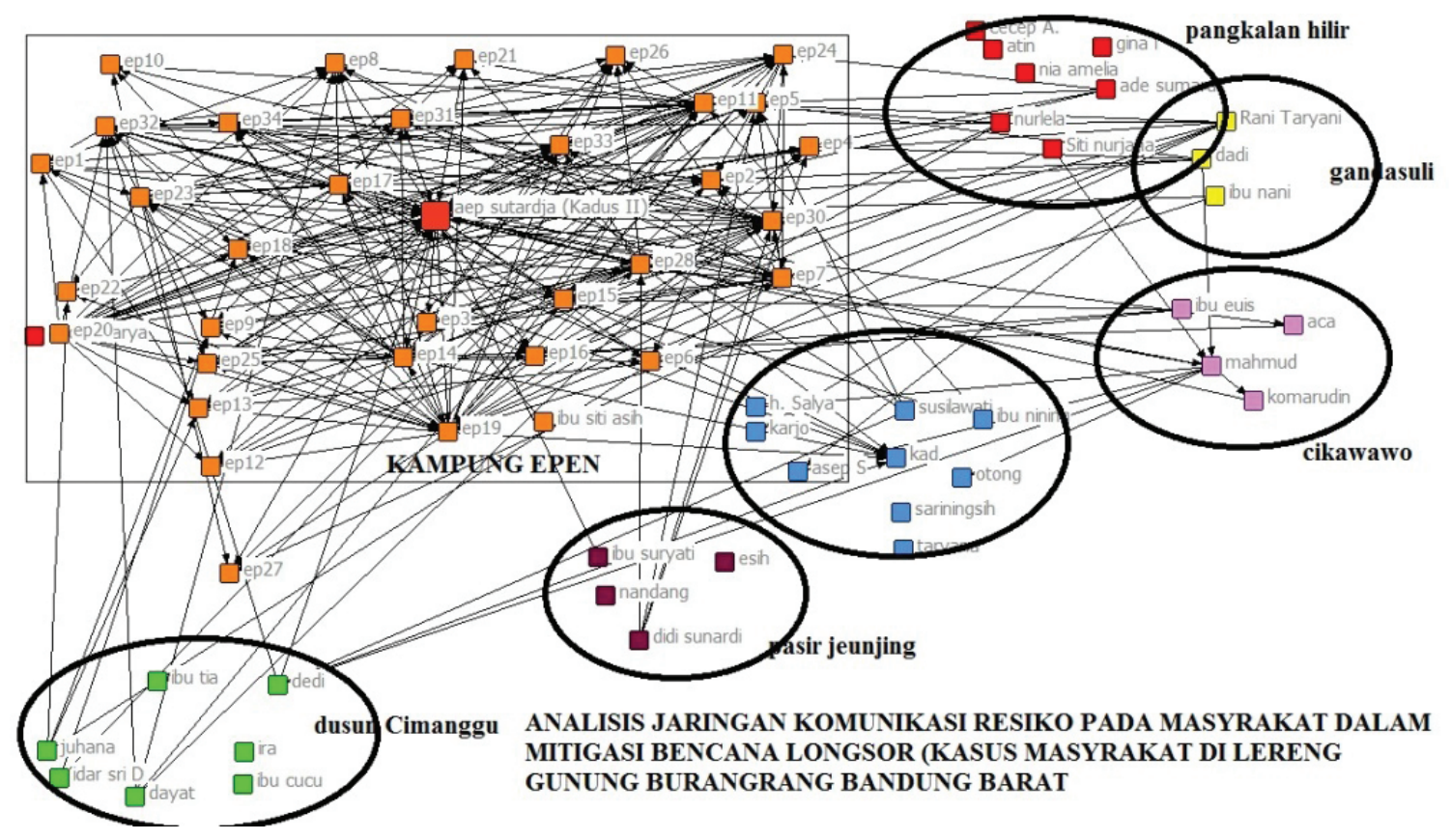

Gambar 1 Sosiogram Jaringan Komunikasi Mitigasi Bencana Longsor Sumber: Hasil Penelitian Penulis, 2017

Berdasarkan sosiogram di atas diketahui bahwa struktur jaringan komunikasi risiko masyarakat di Desa Cimanggu dalam kesiapan menghadapi bencana secara umum berbentuk struktur jaringan komunikasi yang bersifat personal memusat (interlocking personal network). Menurut Rogers dan Kincaid (1981) jaringan personal yang terpusat mempunyai derajat integrasi yang tinggi.

Rogers dan Kincaid menegaskan, individu yang terlibat dalam jaringan komunikasi interlocking terdiri dari individu-individu yang homopili, tetapi kurang terbuka terhadap lingkungannya. Kondisi ini terlihat pada sosiogram di Gambar, di mana terjadi suatu pemusatan arus informasi pada beberapa individu yang memiliki hubungan total relatif lebih banyak daripada individu lainnya pada sistem sosial masyarakat. Pemusatan ini juga terjadi pada tiap-tiap (klik) di mana individu anggota (klik) cenderung berkomunikasi pada satu individu yang berperan sebagai star baik dalam (klik) maupun dalam sistem sosial yang lebih luas.

Dalam jaringan komunikasi ini tampak adanya peranan personal yang terpusat pada satu individu yang memiliki keterhubungan dengan node lain sangat tinggi. Node yang menjadi star dalam (klik) adalah individu yang paling banyak dihubungi oleh masyarakat dalam mencari dan menggali informasi yang berhubungan dengan bencana. Individu memiliki peran sebagai star dalam sosiogram jaringan komunikasi ditunjukkan oleh node yang memiliki derajat konektivitas tertinggi yaitu Aep Sutarja. Beliau merupakan node yang paling banyak dihubungi oleh individu lain serta merupakan individu yang dapat memainkan peran sebagai star.

Umumnya star merupakan pimpinan informal dalam sebuah sistem, Aep merupakan tokoh masyarakat dan juga berperan sebagai kepala dusun Epen. Dalam kepemimpinannya sebagai kepala dusun, Aep senantiasa berkoordinasi dan berkomunikasi dengan warganya 
jika kondisi alam dalam keadaan rawan longsor seperti hujan deras ataupun aliran sungai sedang meluap yang dapat menyebabkan beberapa desa rawan longsor utamanya di permukiman dan jalan desa.

Komunikasi dalam mitigasi bencana ini biasanya pak Aep intensif berkomunikasi dengan petugas yang ada. Jika ada terjadi longsor atau terjadi pergeseran atau retakan tanah biasanya Aep memberikan pengumuman pada warga dengan menggunakan toa masjid, handphone, kentungan, dan komunikasi langsung (tatap muka). Proses komunikasi ini yang dibangun antara Aep dan petugas yang ada kemudian disosialiasasikan secara cepat ke masyarakat luas merupakan bentuk pertukaran infomasi dan meningkatkan aliran pengetahuan dalam masyarakat.

\section{Sentralitas Lokal}

Sentralitas lokal merupakan suatu derajat yang menunjukkan tingkat seberapa besar terhubungnya individu tertentu dalam lingkungan terdekat atau pertetanggaan mereka. Derajat ini menunjukkan jumlah hubungan maksimal yang mampu dibuat individu tertentu dengan individu lain dalam lingkungan terdekat atau tetangga mereka. Berdasarakan hasil analisis dengan menggunakan Ucinet 6.0 diketahui sentralitas lokal pda masyarakat desa Cimanggu dalam jaringan komunikasi risiko bencana longsor disajikan pada tabel 1 .

Tabel 1.

Sentralitas Lokal Jaringan Komunikasi Mitigasi Bencana Longsor

\begin{tabular}{lll}
\hline & OutDegree & InDegree \\
\hline Mean & 4.113 & 4.113 \\
\hline Std Dev & 6.933 & 4.619 \\
\hline Sum & $\mathbf{2 9 2}$ & $\mathbf{2 9 2}$ \\
\hline Minimum & 0.000 & 0.000 \\
\hline Maximum & 36.000 & 36.000 \\
\hline $\begin{array}{l}\text { Network Centralization } \\
\text { (Outdegree) }=46.204 \%\end{array}$ & & \\
\hline
\end{tabular}

Sumber : Hasil Penelitian, 2017

Rata-rata nilai sentralitas lokal pada jaringan ini adalah 4.113. Nilai ini menunjukkan jika rata rata satu individu memiliki atau berhubungan dengan 4 node lainnya pada jaringan. Proses komunikasi yang terjadi ini umumnya pada warga melakukan komunikasi langsung karena rumah warga di dusun Epen ini berkelompok dan relatif berdekatan.

Berdasarkan tabel di atas diketahui bahwa nilai Network Centralization (outdegree) sebesar 46.204 persen, dengan nilai maksimum 36. Nilai ini merupakan derajat keterhubungan individu sebesar 46 persen dari total keterhubungan. Individu yang memiliki nilai sentralitas lokal tertinggi dimiliki oleh node bernama AepSutarja dengan keterhubungan dengan individu lain sebanyak 36 individu. Sedangkan nilai sentralitas lokal minimum pada jaringan ini adalah 0 , ini menunjukkan bahwa ada beberapa individu tidak memiliki koneksi jaringan dengan lingkungannya atau sebagai isolate. Berdasarkan hasil analisis diketahui bahwa individu-individu yang berperan sebagai isolate pada umumnya adalah warga RW 01 yang tinggal relatif pada kawasan dengan topografi yang datar dan relatif tidak terdampak adanya longsor sehingga tidak melakukan komunikasi dalam mitigasi bencana longsor.

\section{Betweenness}

Kebersamaan (betweenness) adalah frekuensi seorang individu melakukan hubungan dengan satu klik di antara klik lainnya. Derajat ini menunjukkan kemampuan individu untuk menjadi perantara/penghubung antara satu aktor dengan aktor lain dalam suatu jaringan. Berdasarkan hasil analisis dengan menggunakan Ucinet 6.0 diketahui nilai kebersamaan pada masyarakat desa Cimanggu dalam jaringan komunikasi risiko bencana longsor disajikan pada tabel 2.

\section{Tabel 2.}

Nilai Kebersamaan (betweennes) pada masyarakat Desa Cimanggu dalam Jaringan

Komunikasi Resiko Bencana Longsor

\begin{tabular}{lll}
\hline & Betweenness & NBetweenness \\
\hline Mean & 26,606 & 0.551 \\
\hline Std Dev & 119.471 & 2.474 \\
\hline Sum & 1889.000 & 39.110 \\
\hline
\end{tabular}


Lanjutan Tabel 2.

\begin{tabular}{lll}
\hline & \multicolumn{1}{c}{ Betweenness } & NBetweenness \\
\hline Minimum & 0.000 & 0.000 \\
\hline Maximum & 982.557 & 20.343 \\
\hline 1. EP 0 Aep sutadja & \\
2. CM 1. Mahmud & \\
3. Ep11 & \\
\hline
\end{tabular}

Sumber: Hasil Penelitian, 2017

Menurut Stoner dan Freeman (1978), konsep kebersamaan mengacu pada tingkat frekuensi seorang individu yang berada diantara individu-individu yang berhubungan dalam suatu jalur komunikasi. Jika seseorang berada dalam suatu jalur komunikasi yang menghubungkan antarindividu atau (klik) maka individu tersebut memiliki posisi yang sentral. Individu dengan nilai kebersamaan tinggi mempunyai potensi kendali komunikasi yang dapat memainkan potensi sebagai broker atau gatekeeper dalam suatu jaringan. Individu lain akan menjadi tergantung kepadanya jika jalur yang menghubungkannya dengan orang lain harus melewati individu tersebut.

Berdasarkan tabel 2 diketahui bahwa nilai maksimum kebersamaan di antara masyarakat dalam jaringan sebesar 982,557 dan nilai minimumnya adalah 0 . Artinya adalah individu yang memiliki nilai kebersamaan maksimum berarti individu tersebut mempunyai kendali komunikasi dalam jaringan komunikasi dalam sistemnya. Individu yang mempunyai nilai kebersamaan maksimum antara lain Aep Sutarja, Mahmud, sebagai aktor (node) yang merupakan ibu kepala dusun atau istri Aep Sutarja. Mereka memiliki beragam jenis informasi berkenaan dengan kesiagaan bencana longsor. Hal ini disebabkan mereka memiliki jalinan hubungan yang intens dengan sumbersumber informasi seperti anggota pengelola air dusun, serta anggota masyarakat yang melakukan ronda (patroli) saat terjadi musim hujan yang sering menyebabkan longsor.

\section{Analisis Aktor}

Dalam melakukan analisis jaringan, peneliti melakukan identifikasi aktor- aktor yang terlibat dalam jaringan komunikasi risiko bencana longsor di Desa Cimanggu kecamatan
Ngamprah. Adapun identifikasi aktor yang dilakukan adalah identifikasi klik, star, bridge, dan isolate. Klik di dalam suatu sistem sosial atau jaringan komunikasi adalah bagian dari sistem (sub-sistem) di mana anggotaanggotanya relatif lebih sering berinteraksi satu sama lain dibandingkan dengan anggotaanggota lainnya dalam sistem komunikasi (Rogers dan Kincaid, 1981). Dalam jaringan komunikasi risiko ini dapat diidentifikasi beberapa klik ataupun sub sistem jaringan komunikasi. Klik yang terbangun pada jaringan komunikasi risiko ini sebagian besar terbentuk atas kedekatan domisili seperti satu RW atau satu Dusun. Star merupakan aktor atau node dalam suatu jaringan komunikasi yang paling dikenal sering dihubungi oleh anggota-anggota lainnya. Star dapat ditunjukkan oleh banyaknya jumlah pilihan terbanyak yang ditujukan kepada seorang aktor/node dari aktor/node lain di dalam suatu sistem jaringan komunikasi. Berdasarkan hasil analisis diketahui beberapa individu yang dapat dikategorikan sebagai star dalam jaringan komunikasi ini. Beberapa individu yang memiliki peran penting dalam jaringan komunikasi ini antara lain; Aep Sutarja, beliau adalah seorang kepala dusun (kadus Epen), Mahmud yang merupakan kadus utama di Cimanggu. Bridge adalah anggota suatu kelompok/sub-kelompok yang berhubungan dengan kelompok/subkelompok lainnya. Berdasarkan hasil analisis diketahui beberapa individu atau node berperan penting sebagai bridge yang menjembatani informasi antar dusun. Beberapa bridge tersebut antara lain Dedi, warga dusun Cikawao yang menjembatani proses komunikasi dengan warga Epen dan Gandosuli. Selain itu, ada beberapa bridge lainnya yang berperan menjembatani arus informasi antar dusun, seperti: Dadi, Mahmud, dan Aep Sutardja. Isolate adalah mereka yang tersisih dalam suatu kelompok/sub kelompok atau individuindividu yang tidak terhubung dengan jaringan informasi yang ada. Berdasarkan hasil analisis diketahui beberapa isolate yang ada pada jaringan komunikasi ini antara lain $\mathrm{Cucu}$, Ira, Esih, Otong, Sariningsih, Tarjana, Cecep, Atin, dan Gina. 


\section{SIMPULAN}

Berdasarkan hasil penelitian yang telah dilakukan, penulis memperoleh temuan bahwa jaringan komunikasi risiko pada masyarakat dalam menghadapi bencana bersifat interlock atau terpusat pada beberapa individu yang berperan sebagai pusat informasi. Selain itu, ada individu yang memiliki peran penting dalam jaringan komunikasi sebagai informan dan beberapa individu yang menjadi star sebagai sumber infomasi penting bagi masyarakat, juga ada individu yang berperan sebagai bridge yang menghubungkan antarklik dalam jaringan komunikasi. Dalam jaringan komunikasi risiko juga terdapat beberapa individu yang tidak terhubung dalam sistem sosial atau jaringan komunikasi, sehingga infomasi tentang potensi bencana longsor tidak dapat tersampaikan dengan cepat pada node/actor sehingga perlu meningkatkan efektivitas jaringan komunikasi risiko, yaitu diperlukannya pola jaringan komunikasi yang lebih intensif lagi, khususnya dalam menghubungkan semua anggota masyarakat yang ada di kawasan rawan longsor ini.

\section{DAFTAR PUSTAKA}

Budi, S., J. Fajar, dan I. Aswad. 2011. Komunikasi Bencana. Yogyakarta: Mata Padi Pressindo.

Bungin, B.H.M. (2007). Penelitian Kualitatif: Komunikasi, Ekonomi, Kebijakan. Publik, dan Ilmu Sosial. Jakarta : Kencana Prenama Media Group.
BNPB(BadanNasionalPenanganan Bencana). 2017. Pengenalan Karakteristik Bencana dan Upaya Mitigasinya di Indonesia. Jakarta: Bakornas PB.

Haddow, G. D. dan Kim S. Haddow. 2008. Disaster Communication in A Changing Media World. Oxford: ButterworthHeinemann.

Puspito, E. 2014. Model Komunikasi Risiko Kesiapan Masyarakat Menghadapi Bencana Gunung Api. Disertasi, Bogor: Institut Pertanian Bogor.

Prasanti, D. dan I. Fuady. 2017. Strategi Komunikasi Dalam Kesiapan Menghadapi Bencana Longsor Bagi Masyarakat di Bandung Barat. Jurnal Trunojoyo. 11(2).

Rudiantoro. 2015. Komunikasi dalam Penanggulangan Bencana. 1: 51-61.

Rogers, E. M., dan L. Kincaid. 1981. Communication Network: Toward A New Paradigm for Research. London (GB): Collier Macmillan Publisher.

Stoner, J.A.F. dan Freeman, R.E. 1978. Management. fifth edition. New Jersey: Prentince-hall International Edition.

Zulkarnain, U. 2015. Analisis Hubungan Jaringan Komunikasi Dengan Perubahan Taraf Penghidupan Dan Pola Fikir Dalam Pemberdayaan Pembudidaya Ikan Di Kabupaten Kampar Riau. Disertasi, Bogor: Institut Pertanian Bogor. 